\title{
Difference in activation capacity between oocytes of Pleurodeles walt matured in vivo and in vitro
}

\author{
AA Bilinkis, YG Yurovitzky, MN Skoblina, \\ EB Abramova, SG Vassetzky *
}

\begin{abstract}
USSR Academy of Sciences, Institute of Developmental Biology, 26 Vavilov street, 117334 Moscow, USSR
\end{abstract}

(4th Franco-Czechoslovak Meeting, Prague 1990)

\begin{abstract}
Summary - Oocytes of Pleurodeles walt were activated after in vivo maturation by needle pricking or electric shock. After in vitro maturation, the oocytes were not activated by these stimuli. Coelomic oocytes and the oocytes which began their maturation in vivo could be activated by electric shock. During in vivo oocyte maturation, the activity of glucose-6-phosphate dehydrogenase (G6PDH), the key enzyme of the pentose phosphate cycle, increased while that of phosphofructokinase, the key enzyme of glycolysis, remained unchanged. During progesterone-induced in vitro oocyte maturation, the activity of both enzymes remained unchanged. Oocytes of Misgurnus fossilis matured in vivo and in vitro were activated spontaneously. No changes in the activity of G6PDH were observed during their maturation. These results suggest a relationship between G6PDH activity in the oocyte and oocyte capacity for activation by needle pricking or electric shock.
\end{abstract}

oocyte maturation / carbohydrate metabollsm / activation / amphiblan / fish

Résumé - Différences de capacités d'activation des ovocytes maturés in vivo et in vitra Des ovocytes de Pleurodeles waltl sont activés par piqûre ou choc électrique après maturation in vivo. Aprés maturation in vitro, les ovocytes ne sont pas activés par ces stimuli. Des ovocytes coolomiques et des ovocytes ayant commencé leur maturation in vivo peuvent être activés par choc électrique. Pendant la maturation de l'ovocyte in vivo, l'activité de la glucose-6-phosphate déshydrogénase (G6PDH), l'enzyme clé du cycle pentose phosphate, augmente, tandis que celle de la phosphofructokinase, l'enzyme clé de la glycolyse, demeure inchangée. Pendant la maturation ovocytaire provoquée in vitro par la progestérone, l'activité des 2 enzymes ne change pas. Les ovocytes de Misgurnus fossilis maturés in vivo et in vitro sont activés spontanément; aucune modification de l'activité G6PDH n'est observée pendant la maturation. Ces résultats suggèrent un rapport entre l'intensité de l'activité G6PDH de l'ovocyte de Pleurodeles waltl et son aptitude à être activé par piqûre ou par choc électrique.

maturation ovocytalre / métabollsme des sucres / activation / amphlblen / polsson

" Correspondence and reprints 


\section{INTRODUCTION}

The degree of oocyte maturation can be evaluated using morphological (metaphase of the 2nd meiotic division) or functional (acquisition of the capacity for activation) criteria. It was shown first in mammals that metaphase II oocytes are not always fertilizable (Thibault, 1977). Also unable to be activated by needle pricking were the oocytes of Bufo arenarum (Legname et al, 1972) and Rana temporaria, matured in vivo beyond the season of reproduction (Sharova, 1989), and the oocytes of Pleurodeles waltl matured in vitro (Bilinkis, 1990). It has been shown in lower vertebrates during gonadotropininduced oocyte maturation that the carbohydrate metabolism changes (Legname et al, 1972; Yurovitzky and Milman, 1973). In the oocytes of $B$ arenarum matured in vivo a correlation has been found between the acquisition of the capacity for activation and changes in carbohydrate metabolism (Legname and Buhler, 1978).

In order to test the hypothesis of a possible influence of the type of carbohydrate metabolism in the oocyte on oocyte capacity for activation, we studied the activity of glucose-6-phosphate dehydrogenase (G6PDH), the key enzyme of the pentose phosphate cycle, and phosphofructokinase (PFK), the key enzyme of glycolysis, in maturing oocytes of $P$ walt and Misgurnus fossilis. Special attention was paid to their capacity for activation.

\section{MATERIALS AND METHODS}

Experime nts were carried out on fully grown oocytes and mature eggs of Pleurodeles walt and Misgurnus fossilis. In order to obtain eggs matured in vivo the females of $P$ walt were injected, 20 to $24 \mathrm{~h}$ before the experiment, with a synthetic analog of LH-RH (synthesized in the Laboratory of Peptide Synthesis, National Cardi- ology Research Center of the USSR Academy of Medical Sciences) at a dose of $4 \mu \mathrm{g} / \mathrm{female}$. The oocytes of $M$ fossilis matured in vivo were obtained after females were injected with 300 IU of human chorionic gonadotropin. For in vitro maturation, fragments of $P$ walt ovary were placed in a modified $\mathrm{K}+$-free Barth solution containing $1.5 \mathrm{~g} / \mathrm{NaHCO}_{3}$ or in $\mathrm{OR}_{2}$ (Wallace et al, 1973) solution; pieces of $M$ fossilis ovary were placed in medium 199 containing $20 \%$ cattle serum. All media were supplemented with $5 \mu \mathrm{g} / \mathrm{ml}$ of progesterone. Oocytes were incubated and all steps were carried out at $18^{\circ} \mathrm{C}$. The completion of oocyte maturation in $P$ waltlii was assayed for the appearance of a characteristic pigment pattern on the animal pole, a white spot with a small dark dot in the middle. This was shown in cytological studies (Skoblina et al, 1984; Taghy-Sadak and Vilain, 1985) to correspond to the metaphase of the 2nd meiotic division. Maturation of $M$ fossilis oocytes in vitro was assayed for germinal vesicle breakdown after fixation with Bau-Kien-Tenig mixture. The mature eggs of $P$ walt were activated with needle pricking or electric shock as described elsewhere (Bilinkis, 1990). The eggs of $M$ fossilis matured in vivo or in vitro underwent spontaneous activation within 20-30 min after ovulation.

Enzyme activity was assayed on 10 portions of oocytes or eggs obtained from different females of $P$ walt in extracts prepared in Ringer solution and 6 portions of oocytes or eggs obtained from different females of $M$ fossilis.

Activity of PFK was assayed according to Underwood and Newsholme (1965): the increase in fructose-1,6-diphosphate was determined after incubation of the extract obtained from 30-60 embryos in a mixture containing $0.0015 \mathrm{M}$ ATP (Calbiochem, Switzerland), $0.003 \mathrm{MgSO}_{4}$, $0.0015 \mathrm{M}$ fructose-6-phosphate (Serva, Germany), $0.005 \mathrm{M}$ mercaptoethanol and $0.05 \mathrm{M}$ Tris$\mathrm{HCl}(\mathrm{pH} \mathrm{8.5)}$. The extracts were prepared in $0.05 \mathrm{M}$ phosphate buffer $(\mathrm{pH} 7.5)$ containing $0.005 \mathrm{M}$ mercaptoethanol $\left(5 \mathrm{~min}\right.$ at $\left.25^{\circ} \mathrm{C}\right)$. The reaction was arrested by hydrochloric acid. Samples to which hydrochloric acid was added before the onset of incubation were used as controls. In the neutralized extracts, fructose1,6-diphosphate was determined using reactions coupled with NAD-H oxidation. A mixture of aldolase, triosephosphate isomerase and alpha-glycerophosphate dehydrogenase was used. 
Activity of G6PDH was assayed according to Glock and McLean (1953) for the reduction of NADP in a system containing $0.05 \mathrm{M}$ Tris $(\mathrm{pH}$ 7.5), $0.003 \mathrm{M} \mathrm{MgSO}_{4}, 0.00015 \mathrm{M}$ NADP (Serva, Germany) and $0.001 \mathrm{M}$ substrate.

\section{RESULTS AND DISCUSSION}

In our previous study (Bilinkis, 1990) it was shown that after both in vivo and in vitro maturation the oocytes of $P$ waltl reached metaphase II but differed in their capacity for activation. After in vivo maturation, the oocytes could be activated by needle pricking or electric shock, whereas after maturation in vitro they were not activated by these stimuli. Incubation of the oocytes in vitro in different media (Ringer, Barth, $\mathrm{K}^{+-}$ free Barth, Barth added with $1.5 \mathrm{~g} / \mathrm{l} \mathrm{NaH}$ $\mathrm{CO}_{3}$, Merriam, $\mathrm{OR}_{2}$ ) gave similar results. The oocytes underwent maturation in all media but could not be activated (Bilinkis, unpublished data).

We have also studied the capacity for activation in the oocytes of $P$ waltt that matured and were ovulated under different conditions. Around $50 \%$ of the coelomic oocytes and those which matured in vivo during the first 8-10 h, but completed maturation in the presence of progesterone in vitro, also acquired the capacity for activa- tion by electric shock. Ovulation did not affect this process (table I).

The activity of G6PDH and PFK was assayed in fully grown oocytes of $P$ walt following their maturation in vivo and in vitro. The activity of G6PDH in the fully grown oocytes or after maturation in vitro was markedly lower than after in vivo maturation, while that of PFK was similar in all three cases (fig 1). According to the ratio between the PFK and G6PDH activities, the pentose phosphate cycle was very active during in vivo oocyte maturation, while glycolysis was relatively more active in the fully grown oocytes and during in vitro oocyte maturation.

We also assayed the activity of G6PDH and PFK in fully grown oocytes of $M$ fossilis and after their maturation in vivo and in vitro. Hormonal stimulation caused no changes in glucose metabolism: the activity of both enzymes remained unchanged during oocyte maturation (fig 2).

The data obtained in this study suggest a relationship between the prevailing type of carbohydrate metabolism in the oocyte of $P$ waltl and the acquisition of a capacity for activation. Only mature eggs, in which carbohydrates were utilized mainly through the pentose phosphate cycle, were capable of activation and subsequent development. Similar data have also been ob-

Table l. Activation by electric shock of Pleurodeles waltl oocytes matured and ovulated in vivo and in vitro.

\begin{tabular}{lccc}
\hline Variant & $\mathrm{n}$ & Activated & $\%$ \\
\hline $\begin{array}{l}\text { Oocytes matured and ovulated in vitro } \\
\begin{array}{c}\text { Oocytes matured in vivo + in vitro } \\
\text { but not ovulated }\end{array}\end{array}$ & 83 & 0 & 0 \\
\begin{tabular}{l} 
Coelomic oocytes \\
\hline
\end{tabular} & 138 & 414 & 50.5 \\
\hline
\end{tabular}




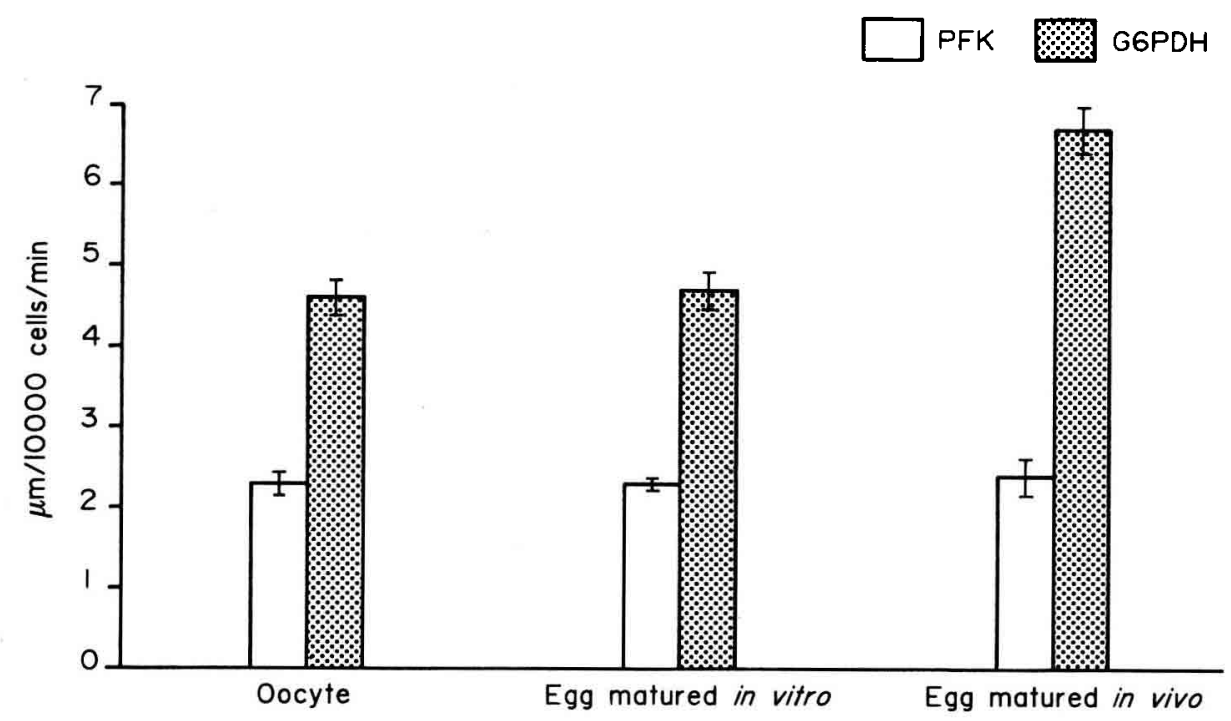

Fig 1. Activity of phosphofructokinase (PFK) and glucose-6-phosphate dehydrogenase (G6PDH) in fully grown oocytes and eggs matured in vitroand in vivo in Pleurodeles walt. Ordinate: enzyme activity.

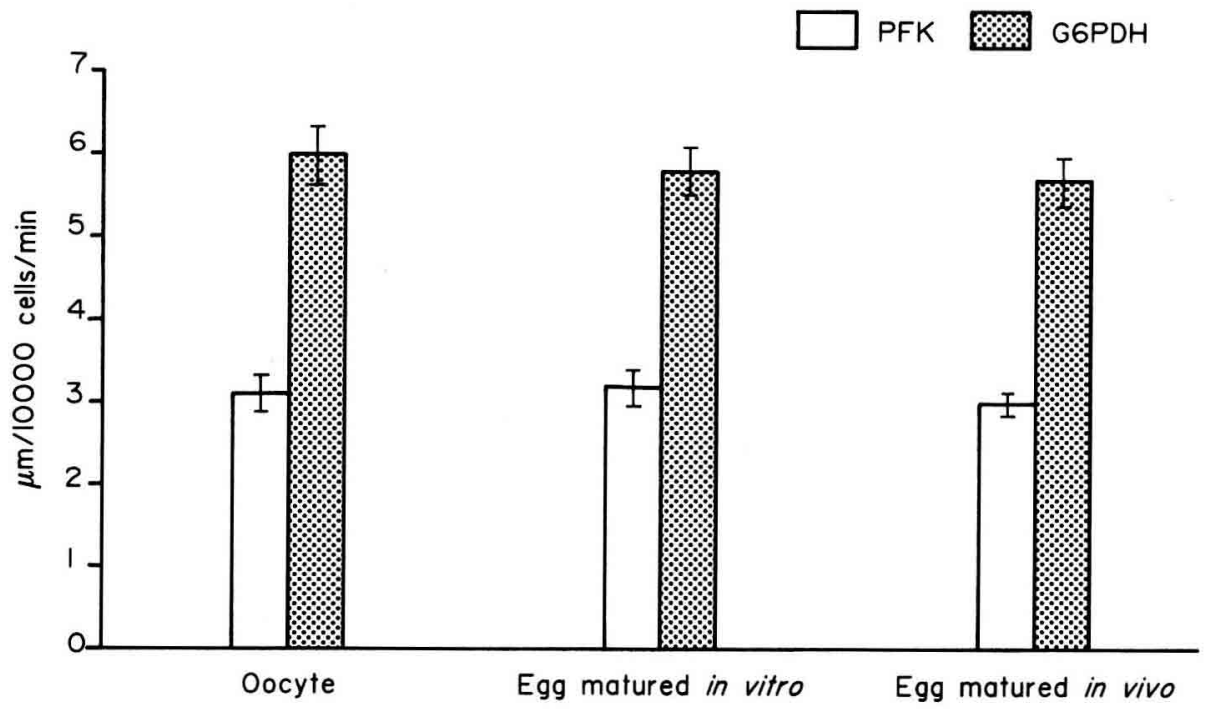

Fig 2. Activity of phosphofructokinase (PFK) and glucose-6-phosphate dehydrogenase (G6PDH) in fully grown oocytes and eggs matured in vitroand in vivo in Misgurnus fossilis. Ordinate: enzyme acivity. 
tained with the oocytes of $B$ arenarum: the mature coelomic eggs obtained in winter could not be fertilized or artificially activated. In these eggs glucose was used predominantly by the glycolytic pathway, whereas in the mature eggs obtained during the normal reproduction season the carbohydrates were mainly used through the pentose phosphate cycle (Legname et al, 1972). Glycose metabolism normally undergqes rearrangement in the fully grown oogyte during the reproduction season (Legname et al, 1976). In $P$ waltl oocytes the glycolytic processes prevailed and the system of carbohydrate metabolism was rearranged only during in vivo maturation. In the oocytes of $M$ fossilis the necessary level of G6PDH activity was already achieved at the time of growth completion and remained unchanged throughout later development. This appears to explain the similar capacity for activation in the oocytes matured in vivo and in vitro. This agrees with results obtained on the oocytes of Xenopus laevis (Dworkin, Dworkin-Rastl, 1989).

It is widely accepted that activation, as one of the main components, comprises a transient increase in free extracellular $\mathrm{Ca}^{2+}$ (Epel, 1990). This mechanism is being studied intensively (Busa et al, 1985; Rusinko and Lee, 1989; Han and Nuccitelli, 1990). It remains to be seen whether the changes in carbohydrate metabolism in in vitro matured oocytes of $P$ waltl eventually affect the systems providing for the mobilization of intracellular $\mathrm{Ca}$.

\section{ACKNOWLEDGMENTS}

The authors would like to express their gratitude to B Goncharov for kindly providing $\mathrm{LH}-\mathrm{RH}$ and $G$ Gause for careful reading of the manuscript and valuable advice.

\section{REFERENCES}

Bilinkis AA (1990) Activation of Pleurodeles walt oocytes matured in vivo and in vitro. Ontogenez 21, 100-101 (in Russian)

Busa WB, Ferguson JE, Joseph SK, Williamson JR, Nuccitelli R (1985) Activation of frog (Xenopus laevis) eggs by inositol triphosphate. 1. Characterisation of $\mathrm{Ca}^{2+}$ release from intracellular stores. J Cell Biol 101, 677682

Dworkin MB, Dworkin-Rastl E (1989) Metabolic regulation during early frog development: glycogenic flux in Xenopus oocytes, eggs, and embryos. Dev Biol 132, 512-523

Epel D (1990) The initiation of development at fertilization. Cell Differ Dev 29, 1-12

Glock GE, McLean P (1953) Further studies on the properties and assay of glucose-6phosphate dehydrogenase and phosphogluconate dehydrogenase of rat liver. Biochem $J$ $55,400-412$

Han JK, Nuccitelli R (1990) Inositol 1,4,5triphosphate-induced calcium release in the organelle layers of the stratified, intact egg of $X$ laevis. J Cell Biol 110, 1103-1110

Legname AH, Buhler MI (1978) Metabolic behavior and cleavage capacity in the amphibian egg. J Embryol Exp Morphol 47, 161-168

Legname AH, Salomon de Legname H, Miceli DC, Sanchez Riera AN (1976) Endocrine control of amphibian oocytes metabolism. Acta Embryol Exp 1, 37-49

Legname $A H$, Salomon de Legname $H$, Sanchez Riera AN, Fernandes SS (1972) Metabolic changes in Bufo arenarum oocytes induced by oviducal secretions. Dev Biol 29, 283-292

Rusinko N, Lee HC (1989) Widespread occurrence in animal tissue of an enzyme catalyzing the conversion of NAD+ into cyclic metabolite with intracellular $\mathrm{Ca}^{2+}$-mobilizing activity. J Biol Chem 264, 11725-11731

Sharova LV (1989) Role of fertilization potential and coupled processes in the early development of Rana temporaria. Abstr candidate dissertation, Moscow, Institute of Dev Biol (in Russian) 
Skoblina MN, Pivnitsky KK, Kondratieva OT (1984) The role of germinal vesicle in maturation of Pleurodeles waltlii oocytes induced by steroids. Cell Differ 14, 153-157

Taghy-Sadak Z, Vilain JP (1985) Exocytosis of glycogen during maturation of amphigian oocytes. Gamete Res 11, 223-236

Thibault C (1977) Are follicular maturation and oocyte maturation independent processes? $J$ Reprod Fertil 51, 1-15

Underwood AH, Newsholme EA (1965) Properties of phosphofructokinase from rat liver and their relation to the control of glycolysis. Biochem J 95, 767-781

Wallace RA, Jared DW, Dumont JN, Sega MW (1973) Protein incorporation by isolated amphibian oocytes. 3. Optimum incubation conditions. J Exp Zool 184, 321-334

Yurovitzky YG, Milman LS (1973) Interconversion of active and inactive forms of phosphorylase and glycogen synthetase in oocytes and embryos of the loach. Roux' Arch Entwicklungsmech Organismen 173, 1-8 